\title{
Groundwater Geophysical Studies in the Developed and Sub-urban BBMP Area, Bangalore, Karnataka, South
} India

\author{
Ramaraju, H. K. ${ }^{1}$, Venkatesha. G. ${ }^{2}$ and Arun Kumar Sharma ${ }^{3}$ \\ 1. SJB Institute of Technology, BGS Health \& Education City, Kengeri, Bangalore-60, India \\ 2. Dayananda Sagar College of Engineering, Kumaraswamy Layout, Bangalore-78, India \\ 3. Space Application Centre, Indian Space Research Organization, Ahmedabad-15, India
}

\begin{abstract}
The projection for groundwater states that the total domestic water demand for greater Bangalore would increase from 1,170 MLD in 2010 to 1,336 MLD in 2016. Dependence on groundwater is ever increasing due to rapid Industrialization \& Urbanization. It is estimated that almost $40 \%$ of the population of Bangalore is dependent on groundwater. Due to the unscientific disposal of domestic and industrial waste generated, groundwater is getting highly polluted in the city. The scale of this impact will depend mainly upon the water-service infrastructure, the superficial geology and the regional setting. The quality of ground water is equally important as that of quantity. Jointed and fractured granites and gneisses constitute the major aquifer system of BBMP (Bruhat Bengaluru Mahanagara Palike) area. Two new observatory borewells were drilled and lithology report has been prepared. Petrographic Analysis (XRD/XRF) and Water Quality Analysis were carried out as per the standard methods. Petrographic samples were analysed by collecting chip of rock from the borewell for every $20 \mathrm{ft}$ depth, most of the samples were similar and samples were identified as Biotite-Gneiss, Schistose Amphibolite. Water quality analysis was carried out for individual chemical parameters for two borewells drilled. The 1st Borewell struck water at $150 \mathrm{ft}$ (total depth-200 ft) \& 2nd struck at $740 \mathrm{ft}$ (total depth-960 ft). Five water samples were collected till end of depth in each borewell. Chemical parameter values such as, Total hardness (360-348, 280-320) mg/ltr, Nitrate (12.24-13.5, 45-48) mg/ltr, Chloride (104-90, 70-70) mg/ltr, Fe (0.75-0.09, 1.288-0.312) mg/ltr etc. are calculated respectively. Water samples were analysed from various parts of BBMP covering $750 \mathrm{sq} \mathrm{kms}$, also thematic maps (IDW method) of water quality are generated for these samples for post-monsoon season. The study aims to explore the sub-surface lithological layers and the thickness of weathered zone, which indirectly helps to know the groundwater pollution source near surface water bodies, dug wells, etc. The above data are interpreted for future ground water resources planning and management.
\end{abstract}

Key words: Lithology, petrography, pollution, urbanization.

\section{Introduction}

The Groundwater Exploitation in South and South-West part of Bruhat Bengaluru Mahanagara Palike is exhaustive nowadays as Water Supply from civic authorities has not yet reached all the new upcoming areas. South and South-West part of Bengaluru has more Gneissic and Granitic exposure which is generally very low Water bearing rock. Water bearing Aquifers are generally above $800 \mathrm{ft}$ in these regions. Two observatory borewells were drilled

Corresponding author: Ramaraju, H. K., Ph.D., professor, research fields: water quality/quantity \& environment. in two regions i.e. Vijaynagar of South-West region and Thalaghattapura (Sub-Urban) area in Kanakapura road of South region. At vijaynagar water struck at $150 \mathrm{ft}$ and was drilled up to $200 \mathrm{ft}$, it has Gneiss with amphibolite enclaves. In second observatory borewell it contains only gneiss and first water struck at $740 \mathrm{ft}$ and was drilled up to $960 \mathrm{ft}$. Water quality map for both borewell is generated and it indicates the amount of pollution. The results indicate the present groundwater table quality and quantity status of South and South-West part of Bruhat Bengaluru Mahanagara Palike area. 


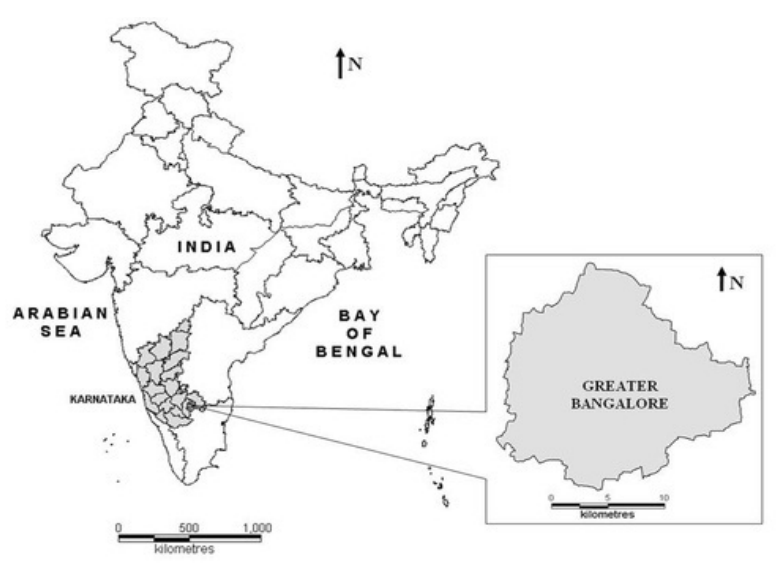

Fig. 1 Study area.

\section{Lithological Profile of Borewells}

The lithological profile of two borewells was prepared after analyzing the rock chip sample from two observatory borewells.

In the drilled borewell of Vijaynagar samples were similar, average depth was considered for profile section and the dark gray colored chip was obtained below the weathered rock zone. Hornblende and plagioclase are major mineral phases and sphene; ilmenite etc. are in minor phases. At some places Hornblende is altered to biotite, plagioclase is colorless with Polysynthetic Twinning and is invariably kaolinized. The rock shows well developed schistosity. One thin Quartz vein cutting across the schistosity is also seen. The rock chip is identified as schistose amphibolite up to $3 \mathrm{~m}$ Red soil was obtained, from $3 \mathrm{~m}$ to $17 \mathrm{~m}$ highly weathered gneiss was obtained, from $46 \mathrm{~m}$ to $58 \mathrm{~m}$ weathered/fractured gneiss in which amphibolite enclaves were obtained, after that hard gneissic rock continued. The drilling was stopped at $200 \mathrm{ft}$.

The second borewell in Talaghattapura, samples here were also similar and profile section was prepared. The light grey chip was obtained. The rock is banded, medium to coarse grained and exhibits Gneissic texture. Quartz and Plagioclase are major minerals. Plagioclase laths are subhedral which shows polysynthetic twinning at places and invariably kaolinized and sericitised quartz exhibits triple point junction. Stretching and sub-grain formation is observed. K-Feldspar shows dusky appearance due to alteration. At places, perthitic intergrowth is also noticed. Biotite is brown to dark brown colored, pleochroic in nature with one set of prominent cleavage and shows parallel extinction. It is aligned parallel to the banding.

Zircons are euhedral and show prominent zoning at places. Apatite occurs as fine colorless needles with grey interference color and straight extinction. Chlorite and Muscovite occurs as alteration products of biotite and plagioclase respectively. The Rock chip is identified as biotite gneiss.

Table 1 Lithological report of Borewell in Vijaynagar.

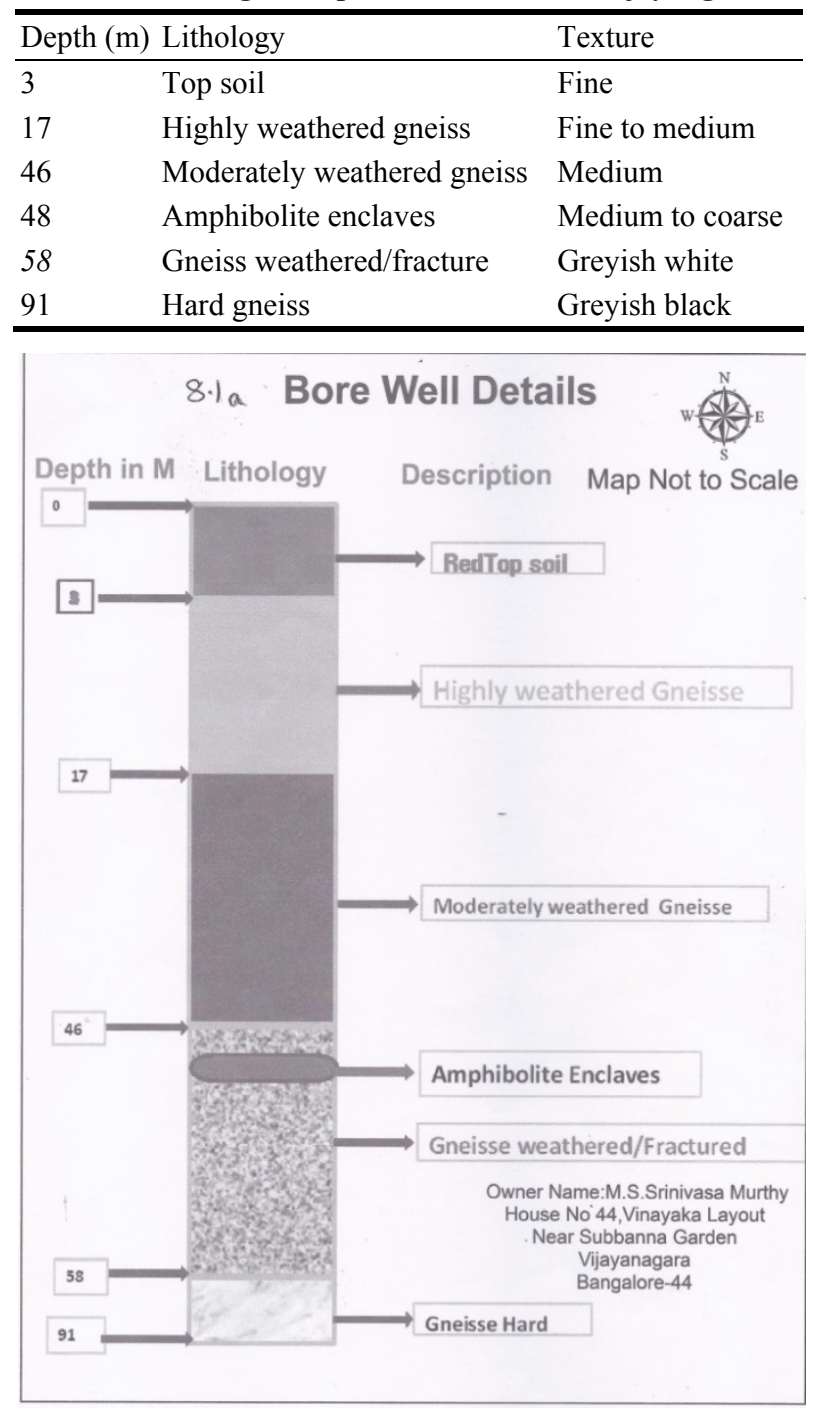

Fig. 2 Lithological profile of Borewell in Vijaynagar. 
Table 2 Lithological report of Borewell in Talaghattapura.

\begin{tabular}{lll}
\hline Depth $(\mathrm{m})$ & Lithology & Texture \\
\hline 3 & Top soil & Fine \\
18 & Highly weathered gneiss & Fine to medium \\
224 & Hard gneiss & Medium \\
291 & Fractured gneiss & Medium to coarse \\
\hline
\end{tabular}

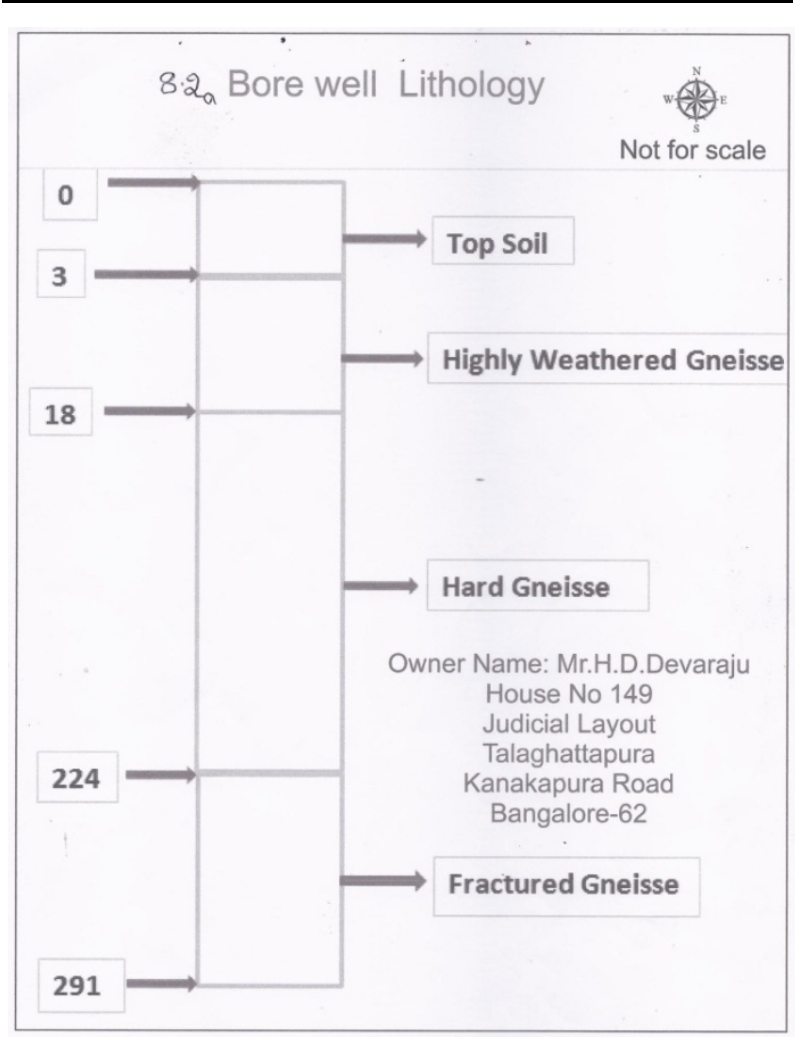

Fig. 3 Lithological profile of Borewell in Talaghattapura.

\section{Water Quality of Observatory Borewells}

Water quality is the most important factor as it gives detailed view of current pollution status of Groundwater. The groundwater pollution mainly depends on the geomorphology, structure of sub-surface. The places having more fractures will get more polluted due to large infiltration from polluted lakes, sewage pipelines and other Industries. Thematic maps are generated using IDW (Inverse Distance Weightage) method using ArcGIS 9.3. The South and South-West region can be generally represented by two observatory borewells.

In the first observation borewell water struck at 150 $\mathrm{ft}$ level and further water samples were taken at average depths of $180 \mathrm{ft}, 190 \mathrm{ft}$ and $200 \mathrm{ft}$.

Most of the parameters such as Turbidity, Alkalinity, Magnesium, and Sodium are above the permissible limits. High amount of Nitrate is present; $\mathrm{Fe}$ is also high. Variation of water quality is represented in Fig. 3.

In the second observation borewell water struck at $740 \mathrm{ft}$ and further water samples were taken at average depths of $780 \mathrm{ft}, 820 \mathrm{ft}, 860 \mathrm{ft}, 900 \mathrm{ft}, 960 \mathrm{ft}$.

In this area also Turbidity is not permissible, Alkalinity is not agreeable in some samples, Magnesium is not permissible, Sodium is not permissible, and $\mathrm{Fe}$ is also high. Variation of water quality is represented in Fig. 3.

\subsection{General Water Quality of BBMP Area}

The general water quality of South and South-West area are little bit more in South-West for Alkalinity, only some 2 or 3 samples are not permissible for Chloride, one sample in Magnesium is not permissible limits.

\subsection{Water Quality of Whole BBMP Area}

Whole BBMP (Bruhat Bengaluru Mahanagara Palike) covers an area of $750 \mathrm{~km}^{2}$ approximately. Totally 176 samples were collected for whole greater Bengaluru area. The data in the below table represent post-Monsoon season representation only. Water quality of samples obtained is analyzed using standards of BIS.

The study area is mainly divided into 4 major grids i.e. N-E, N-W, S-E, S-W, later numbering is done in the continuous pattern. Each complete grid covers an area of 2 square kilometers. About 176 water sampling points are selected based on hydro-geology, domestic/industrial/commercial set up. All the chemical parameters such as electrical conductivity, calcium, sodium, $\mathrm{pH}$, Chloride etc. are considered for comparison. Further water prospect zones are also needed to be established in Bengaluru BBMP area with the help of remote sensing and GIS. Water 
Table 3 Chemical parameters of Talaghattapura observatory Borewell.

\begin{tabular}{|c|c|c|c|c|c|c|c|c|c|c|c|c|c|}
\hline $\begin{array}{l}\text { Depth } \\
\text { (in feet) }\end{array}$ & $\mathrm{pH}$ & $\begin{array}{l}\text { Conductivity } \\
(\mu \text { Mhos })\end{array}$ & $\begin{array}{l}\text { Turbidity } \\
\text { (NTU) }\end{array}$ & $\begin{array}{l}\text { Alkalinity } \\
\text { (mg/ltr) }\end{array}$ & $\begin{array}{l}\text { Acidity } \\
\text { (mg/ltr) }\end{array}$ & $\begin{array}{l}\text { Chloride } \\
\text { (mg/ltr) }\end{array}$ & $\begin{array}{l}\text { Total } \\
\text { hardness } \\
(\mathrm{mg} / \mathrm{ltr})\end{array}$ & $\begin{array}{l}\mathrm{Ca} \\
\text { hardness } \\
(\mathrm{mg} / \mathrm{ltr})\end{array}$ & $\begin{array}{l}\mathrm{Mg} \\
\text { hardness } \\
\text { (mg/ltr) }\end{array}$ & $\begin{array}{l}\mathrm{Na} \\
(\mathrm{mg} / \mathrm{ltr})\end{array}$ & $\begin{array}{l}\mathrm{K} \\
(\mathrm{mg} / \mathrm{ltr})\end{array}$ & $\begin{array}{l}\mathrm{Fe} \\
(\mathrm{mg} / \mathrm{ltr})\end{array}$ & $\begin{array}{l}\text { Fluorides } \\
\text { (mg/ltr) }\end{array}$ \\
\hline 740 & 9.18 & 0.40 & 49.6 & 200 & nil & 70 & 280 & 120 & 160 & 45 & 34 & 1.288 & 0.046 \\
\hline 780 & 8.76 & 0.36 & 42.4 & 196 & nil & 80 & 440 & 180 & 260 & 54 & 52 & 0.430 & 0.115 \\
\hline 820 & 8.69 & 0.47 & 35.6 & 220 & nil & 90 & 280 & 200 & 80 & 89 & 7 & 1.471 & 0.313 \\
\hline 860 & 8.53 & 0.57 & 26.0 & 188 & nil & 80 & 360 & 200 & 160 & 70 & 18 & 0.516 & 0.112 \\
\hline 900 & 8.58 & 0.47 & 13.1 & 232 & nil & 90 & 400 & 150 & 250 & 60 & 11 & 0.363 & 0.070 \\
\hline 960 & 8.90 & 0.44 & 13.0 & 240 & nil & 70 & 320 & 168 & 152 & 48 & 10 & 0.312 & 0.062 \\
\hline
\end{tabular}

OB_Well 2: Mr. H. D. Devaraju, House No-149, 3rd Main, Judicial Layout, Talaghattapura, Kanakapura Road, Bangalore-62.

\section{Table 4 Chemical parameters of Vijaynagar observatory Borewell.}

\begin{tabular}{|c|c|c|c|c|c|c|c|c|c|c|c|c|c|c|c|c|c|c|c|}
\hline $\begin{array}{l}\text { Depth } \\
\text { (feet) }\end{array}$ & $\mathrm{pH}$ & $\begin{array}{l}\text { Conducti } \\
\text { vity } \\
(\mu \mathrm{Mhos})\end{array}$ & $\begin{array}{l}\text { Turbidity } \\
\text { (NTU) }\end{array}$ & $\begin{array}{l}\text { Alkalinity } \\
\text { (mg/ltr) }\end{array}$ & $\begin{array}{l}\text { Acidity } \\
(\mathrm{mg} / \mathrm{ltr})\end{array}$ & $\begin{array}{l}\text { Chloride } \\
\text { (mg/ltr) }\end{array}$ & $\begin{array}{l}\text { Sulphates } \\
(\mathrm{mg} / \mathrm{ltr})\end{array}$ & $\begin{array}{l}\text { Total } \\
\text { hardness } \\
\text { (mg/ltr) }\end{array}$ & $\begin{array}{l}\mathrm{Ca} \\
\text { hardness } \\
\text { (mg/ltr) }\end{array}$ & $\begin{array}{l}\mathrm{Mg} \\
\text { hardness } \\
(\mathrm{mg} / \mathrm{lt})\end{array}$ & $\begin{array}{l}\mathrm{Na} \\
(\mathrm{mg} / \mathrm{ltr})\end{array}$ & $\begin{array}{l}\mathrm{K} \\
(\mathrm{mg} / \mathrm{ltr})\end{array}$ & $\begin{array}{l}\text { Nitrates } \\
(\mathrm{mg} / \mathrm{ltr})\end{array}$ & $\begin{array}{l}\mathrm{Fe} \\
(\mathrm{mg} / \mathrm{ltr})\end{array}$ & $\begin{array}{l}\text { Total } \\
\text { solids } \\
(\mathrm{mg} / \mathrm{tr})\end{array}$ & $\begin{array}{l}\text { Volatile } \\
\text { solids } \\
(\mathrm{mg} / \mathrm{ltr}) \\
\end{array}$ & $\begin{array}{l}\text { Dissolved } \\
\text { solids } \\
(\mathrm{mg} / \mathrm{ltr})\end{array}$ & $\begin{array}{l}\text { Suspended } \\
\text { Solids } \\
(\mathrm{mg} / \mathrm{ltr})\end{array}$ & $\begin{array}{l}\text { Fluorides } \\
\text { (mg/ltr) }\end{array}$ \\
\hline 150 & 7.82 & 0.82 & 27.0 & 424 & Nil & 104 & 66 & 360 & 200 & 160 & 70 & 17 & 12.24 & 0.75 & 1000 & 210 & 790 & 60 & 0.522 \\
\hline 180 & 7.78 & 0.81 & 13.5 & 440 & Nil & 96 & 30 & 344 & 208 & 136 & 67 & 14 & 11.0 & 1.03 & 880 & 110 & 770 & 80 & 0.008 \\
\hline 190 & 7.97 & 0.71 & 4.5 & 384 & Nil & 80 & 23 & 296 & 200 & 96 & 57 & 8 & 12 & 0.43 & 840 & 120 & 720 & 72 & 0.009 \\
\hline 200 & 8.0 & 0.80 & 11.5 & 456 & Nil & 100 & 54 & 356 & 192 & 164 & 70 & 9 & 14.62 & 0.30 & 966 & 184 & 782 & 68 & 0.005 \\
\hline 200 & 8.92 & 0.82 & 17.2 & 464 & Nil & 100 & 28 & 356 & 204 & 152 & 00 & 4 & 17 & 0.31 & 848 & 96 & 752 & 66 & 0.014 \\
\hline 200 & 7.96 & 0.82 & 12.5 & 464 & Nil & 90 & 21 & 348 & 196 & 152 & 00 & 4 & 13.5 & 0.09 & 850 & 90 & 760 & 70 & 0.015 \\
\hline
\end{tabular}

OB_Well_1: Mr. M. S. Srinivasa Murthy, House No-44, Vinayaka Layout, 3rd Stage, Near Subanna Garden, Vijayanagara, Bangalore-44. 

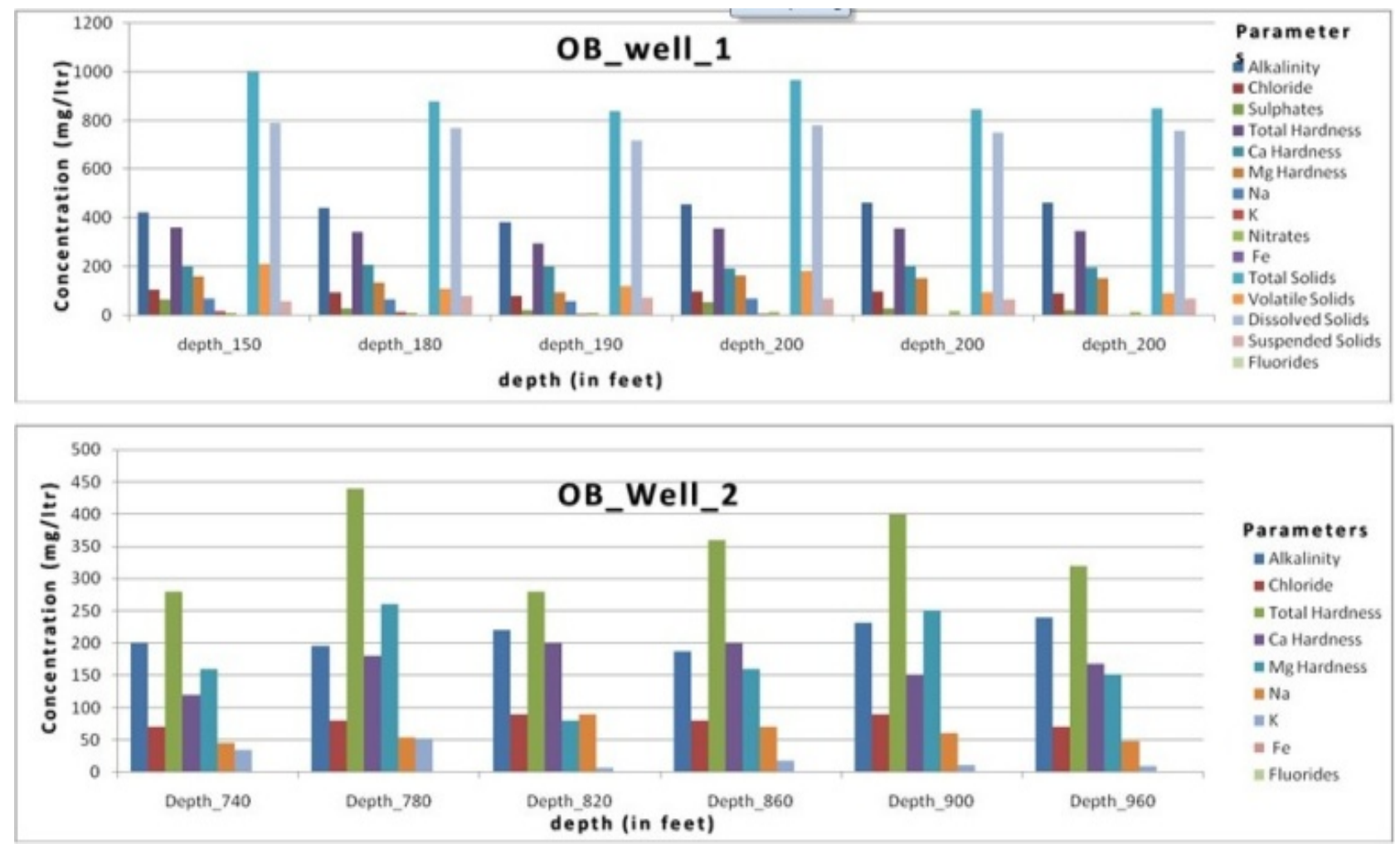

Fig. 4 Depth wise chemical parameters.

Table 5 Water quality characteristics (for 176 samples).

\begin{tabular}{ll}
\hline Parameters & $\begin{array}{l}\text { \% of samples above Desired limits } \\
\text { (out of 176 samples) }\end{array}$ \\
\hline $\mathrm{pH}$ & 1.7 \\
$\mathrm{TDS}$ & 57.95 \\
Calcium & 19.3 \\
Magnesium & 1.13 \\
Chloride & 3.46 \\
Total hardness & 12.13 \\
Sodium & 9.09 \\
Potassium & 0.56 \\
Nitrate & 5.13 \\
Sulphate & Within limits \\
Fluoride & Within limits \\
Iron & 6.81 \\
Alkalinity & 59 \\
\hline
\end{tabular}

quality should be improved by recycling the waste water and also by improving good drainage system.

Out of 176 water samples analyzed $14.66 \%$ of the samples are above the permissible limits. In this 176 samples chemical parameters such as Sulphate and Fluoride are within the permissible limits. The water quality is deteriorating day by day due to increased urbanization and industrialization. Identifying the source pollutant is the main job for the current situation of Bengaluru. Due to rapid urbanization Nitrate quantity is increasing rapidly in groundwater (varies from 41 to $418 \mathrm{mg} / \mathrm{l}$ in summer, the permeability of BBMP area varied from 0.14 to 0.39 $\mathrm{m}$ /day), also the Heavy metals concentration is increasing due to industrialization. Higher concentration of N, P, K, values \& eutrofication can be observed in the lake water.

\section{Conclusion}

Study of lithological profile is important in any groundwater quality as it gives information regarding rock properties such as porosity, permeability, hardness, weathered zone and also tectonic disturbances. The two observatory Borewells have supported the gneissic terrain of Bengaluru city. First observatory Borewell has obtained mainly schistose amphibolite, whereas second observatory Borewell has biotite gneiss. It is the continuation of Dharwar craton. The rock is very 

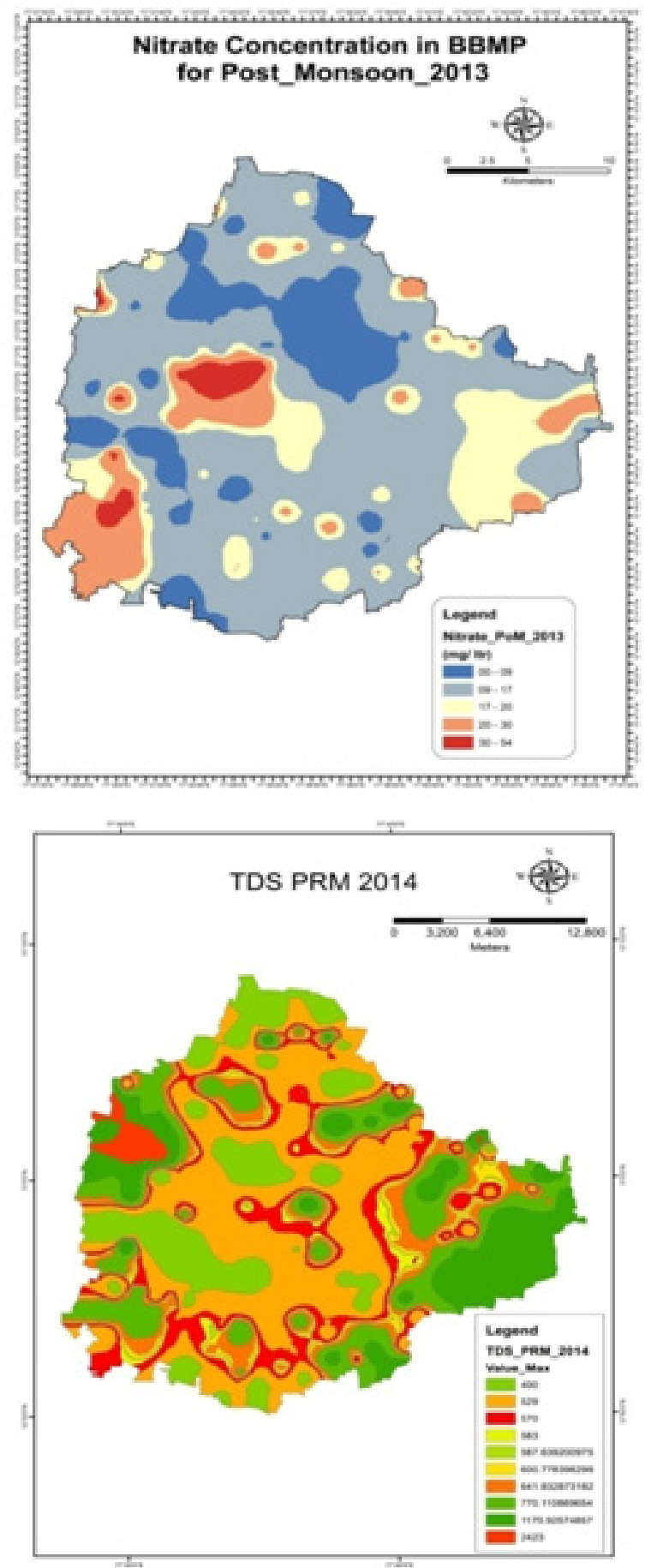

Fig. 5 Water quality maps generated using ArcGis (IDW method). hard and aquifer formation is very rare, but still secondary porosity in hard rock area is very important. This is having a direct impact of chemical constituents in the urban area; infiltration of pollutants may be linked to changes in the water quality. The chemical pollution gets diluted during monsoon season and gets increased rapidly during pre-monsoon season. As the tables indicate most of the parameters are above the permissible limits. All precautionary measures should be taken to protect environment.

\section{Acknowledgment}

Authors are thankful to Dr. Ganesha Raj \& Vikas Patel, ISRO-RESPOND for their financial \& technical support. Principal, SJB Institute of Technology permits us to prepare the paper and Dayananda Sagar College of Engineering management helps us to carry out the research.

\section{References}

[1] Department of Mines and Geology. 2011. "Groundwater Hydrology and Groundwater Quality in and around Bengaluru City."

[2] Sekhar, M., and Mohan Kumar, M. S. 2009. "Geo-Hydrological Studies along the Metro Rail Alignment in Bangalore." Department of Civil Engineering, Indian Institute of Science, Bangalore.

[3] Ramesh, A., Nagendra Prakash, B. S., Sivapullaiah, P. V., and Sadhashivaiah, A. S. 2012. "Assessment of Ground Water Quality in Designated Peenya Industrial Area and Estate, Bangalore, India-A Case Study.” International Journal of Environmental Protection 2 (6): 21-5.

[4] Central Ground Water Board. 2008. Ground Water Information Booklet. Bangalore Urban District.

[5] Sitharam, T. G., Ganesha Raj, K., Anbazhagan, P., and Mahesh, U. G. 2007. "Use of Remote Sensing Data and Past Earthquake Events for Deterministic Seismic Hazard analysis of Bangalore." In Proceeding of the Conference on Advances in Space Science and Technology, 290-7. 
About the Author Dr. H. K. Ramaraju

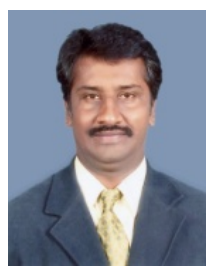

Dr. Ramaraju. H. K. (49), Post Graduate in Environmental Engineering and Ph.D. in Civil-Environmental Engineering from University Visveswaraya College of Engineering, Bangalore. He has published/presented 91 research papers in National/International Journals/Seminars and Edited 5 technical volumes. On invitation Prof. Ramaraju has visited United Kingdom, Italy, France, Switzerland, China, Malaysia, Nepal, Egypt, Norway, Netherlands, United States of America (USA), Singapore, Australia, Srilanka and Mauritius to share innovative actions for Water \& Sanitation. He has been honored with Sir M. Vesveswaraya Prathibha Purakar in the year 2000 by Engineers association, Bangalore. He is a recipient of Rajiv Gandhi Parisara Prashasti (Award for excellence in environment-related work) with cash prize of rupees one lakh from Government of Karnataka on 5th June 2005. He is also receiptant of Bhartiya Shiksha Ratan Award for Excellence in their field Excellence in teaching, R \& D in water and sanitation field; Individual Achievements and National Development Constituted by Global Society for Health \& Educational Growth (GSHEG), New Delhi (12th February 2007). Indian Water Works Association awarded: Brijnandan Sharma Award for the services in water/waste water field with a cash prize of Rs 50,000/- at 40th Annual Convention held at Indore, Madhya Pradesh (Feb 2008). He also got UNESCO-Netherlands Fellowship (July 2009) for a short term course on Decentralized Water supply \& sanitation, Delft, Netherlands. Bruhath Bangalore Mahanagara Palike (BBMP: Greater Bangalore), Government of Karnataka honored Ramaraju with Nada Prabhu Kempe Gowda Award for the services in the field of Environment at 500th year of Founders Day Celebrations of Bangalore (18 April 2011).

He was a Professor in Civil and Environmental Engineering, Faculty of Engineering-Civil, University Visveswaraya College of Engineering (UVCE), Bangalore University and at Dayananda Sagar College of Engineering, Bangalore as Professor \& Head of Civil Engineering. Presently he is at SJB Institute of Technology as Professor of Civil Engineering. He is guiding three Ph.D. students (His Research projects are funded by AICTE, UGC, VTU \& ISRO, Rural Development \& Panchayath Raj Department amounting to Rs 75 lakhs +) on E-waste management, Municipal Solid Waste Management, On-site sanitation systems and been active with a number of NGO's in the field of environment and practical consumer awareness on Aforestation and Soil conservation, Rain water, Roof top harvesting, watershed: Ground water management, Importance of water quality/Quantity, it's impact on Health and Climate Change/Global Warming. 